\title{
Pengaruh Pola Asuh Orangtua Terhadap Prestasi Belajar Dan Perilaku Sosial Peserta Didik SD Di Kecamatan Tamalanrea Kota Makassar
}

\section{The Influence of Parenting Styles on Learning Achievement and Social Behavior of Elementary School Students in Tamalanrea District, Makassar City}

\author{
Ade Rahmi ${ }^{1}$, Muhammad Yunus ${ }^{2}$, Mas'ud Muhammadiah ${ }^{2}$ \\ ${ }^{1}$ Dinas Pendidikan Kota Makassar, Sulawesi Selatan \\ ${ }^{2}$ Program Studi Studi Pendidikan Dasar, Program Pascasarjana, Universitas Bosowa \\ E-mail: aderahmi10@gmail.com
}

Diterima: 10 Januari 2021/Disetujui 09 Juni 2021

\begin{abstract}
Abstrak. Pola asuh dianggap menjadi faktor penentu terhadap kemampuan akademik dan kemampuan sosial anak, di antaranya adalah perilaku sosial dan prestasi belajar. Untuk itu peneliti tertarik untuk mengkaji secara ilmiah pengaaruh polaasuh orangtua terhadap perilaku sosial dan hasil belajar peserta didik SD di Kecamatan Tamalanrea Kota Makassar. Penelitian ini bertujuan untuk mendeskripsikan pola asuh yang di terapkan orangtua pada siswa SD, pengaruh pola asuh orangtua dalam membentuk perilaku sosial peserta didik SD, pengaruh pola asuh orangtua terhadap pretasi belajar peserta didik SD di Kecamatan Tamalanrea Kota Makassar dengan menggunakan Teknik analisis statistik deskriptif. Subjek penelitian ini adalah peserta didik kelas V Sekolah Dasar di Kecamatan Tamalanrea Kota Makassar Tahun ajaran 2020/2021 dengan jumlah siswa 50 orang. Hasil penelitian menunjukkan bahwa pola asuh yang banyak digunakan oleh orangtua di SD Kecamatan Tamalanrea Kota Makassar adalah pola asuh demokratis dan terdapat pengaruh dari pola asuh orangtua terhadap prestasi belajar dan perilaku sosial peserta didik SD di Kecamatan Tamalanrea Kota Makassar. Hal ini dibuktikan dengan adanya nilai prestasi belajar yang lebih baik pada buku laporan hasil belajar peserta didik yang diasuh dengan cara demokratis, sekaligus respondens terbanyak yaitu 28 orang $(56 \%)$ dari 50 responden telah menjawab sangat setuju dengan pernyataan pola asuh demokratis orangtua sngat berpengaruh terhadap prestasi belajar seklah dasar di Kecamatan Tamalanrea Kota Makassar. Sehingga, Nilai Asymptotic Shig sebesar 0,000 yang artinya kurang dari Sig alpha yang ditentukan yaitu 5\% $(0,05)$ maka ada pengaruh yang signifikan dengan pengaaruh pola asuh orang tua terhadap prestasi belajar dan perilaku sosial peserta didik.
\end{abstract}

Kata Kunci: Pola Asuh Orangtua, Prestasi Belajar, Dan Perilaku Sosial.

\begin{abstract}
Parenting is considered to be a determining factor for children's academic abilities and social abilities, including social behavior and learning achievement. For this reason, researchers are interested in scientifically examining the effect of parenting on social behavior and learning outcomes of elementary school students in Tamalanrea District, Makassar City. This study aims to: (1) describe the parenting styles applied by parents to elementary school students in Tamalanrea District, Makassar City, (2) describe the effect of parenting in shaping the social behavior of elementary school students in Tamalanrea District, Makassar City, and (3) describe the influence of parenting styles on the learning achievement of elementary school students in Tamalanrea District, Makassar City using descriptive statistical analysis techniques. The subjects of this study were students of grade V Elementary School (SD) in the Tamalanrea District of Makassar City for 2020/2021 academic year with 50 students. The results showed that the parenting style that is mostly used by parents in SD, Tamalanrea District, Makassar City is democratic parenting and there is an effect of parenting on learning achievement and social behavior of elementary school students in Tamalanrea District, Makassar City. This is evidenced by the existence of a better learning achievement value in the learning outcomes report book of students who are cared for in a democratic way, as well as the largest number of respondents, namely 28 people (56\%) out of 50 respondents answered strongly agree with the statement that democratic parenting has an effect on learning achievement of elementary school students in the Tamalanrea District of Makassar City. The parenting style that can be a role model for all parents is democratic parenting, because it will make children confident and also easy to communicate with other individuals. The social behavior of students can be clearly illustrated in their daily life, especially at school. The communication and interaction built by students is reflected in the behavior patterns and habits they get at home, especially in social behavior. Thus, the Asymptotic Sig value is 0,000, which mean that it is less than the specified Sig alpha, which is $5 \%$ (0.05), so there is a significant influence on the effect of parenting styles on learning achievement and social behavior of students.
\end{abstract}

Keywords: Parenting Styles, Learning Achievement, and Social Behavior

\section{Pendahuluan}

Pola asuh anak, merupaakan pola perilaku yang di terapkan orangtua pada anak-anaknya yang bersifat konsisten, dari waaktu ke waktu (Jainuddin, 2019). Pola asuh anak yang di terapkan oleh orangtua berpeengaruh pada pembentukan pda 
kepriibadian anak. Keluarga, meruupakan tempat sosialisasi pertama pada anak. Seorang anak akan meniru perilaku dari orangtuanya baik itu perilaku baik maupun perilakuu yang kurang baik, kecuali orang tua dapat memberikanpendidikan, yang sesuai bagi anak. Hal itulah, yang nanti akan di bawa anak sampai dewasa hingga tua. "Jangan mengkuatirkan bahwa anakanak sehingga tidak mendengarkan anda, tapi kuatirlah bahwa mereka, selalu mengamati anda", begitulah yang selalu dikatakan oleh Rhobert Flughum (Lestari, 2008). Oleh karena itu, pembelajaran tentang sikap, perilaku, dan bahasa yang baik akan membentuk kepribadian anak yang baik pula. Orang tua, merupakan pendidik, yang paling utama, guru serta teman sebaya merupakan lingkungan yang kedua bagi anak. Hal ini sangat sesuai dengan pendapat Elizabeth (1997) yang menguungkapkan, bahwa orang yang paling penting bagi anak adalah orangtua, guru, serta teman sebaya. Menurut Sardiman (1990) motivasi adalah serangkaian usaha untuk menyediakan kondisi-kondisi tertentu, sehingga seseorang mau dan ingin melakukan sesuatu, dan bila ia tidak suka, maka akan berusaha untuk meniadakan atau mengelakkan perasaan tidak suka itu. Suatu proses belajar terkadang mencapai hasil yang tidak maksimal, hal itu disebabkan ketiadaan kekuatan yang mendorong (motivasi).

Keluarga adalah sebagai satuan uniit sosial terkecil, merupakan lingkuungan pendidikan yang paling utama dan pertama. Dalam arti, keluarga meruupakan lingkungan yang pada paling bertanggung jawab mendidik anak-anaknya. Pendidikan yang di berikan orangtua seharusnya memberikan dasar bagi pendidikan, proses sosialisasi, serta kehidupannya di masyarakat. Sesuai yang tertera dalam Undang-Undang Nomor 20 Tahun 2003 Tentang Sistem Pendidikan Nasional pasal 1 ayat 1 (dalam Darmawan dkk, 2021) menyatakan baahwa pendidikan adalah suatu usaha sadar dan terencana untuk mewujudkan suasana belajar proses pembelajaran agar peserta didik secara aktifmengembangkan potensi dirinya untuk memiliki kekuatan spiritual keagamaan, pengendalian diri, kepribadian, kecerdasan, akhlak mulia, serta keterampilan yang diperlukan dirinya, masyarakat, bangsa, dan negara.

Dalam hal ini, orangtualah memegang peran membentuk sistem interaksi yang intim sertaberlangsung lama di tandai loyalitas pribadi, cinta kasih, dan hubungan yang penuh kasih sayang. Peranan orangtua adalah dengan membenahi pada mental anak. Terbentuknya kepribadian, dan kreativitas anaak merupakan modal bagi penyeesuaian diri anak dan lingkungannya, serta tentunya memberikan dampak bagi kesejahteraan keluarga secara menyeluruh. Pola asuh orangtua digunakan sebagai salah satu variabel dalam penelitian ini karena peran orangtua masih dominan mengingat porsi waktu yang lebih besar untuk kegiatan siswa di luar sekolah yang diasumsikan di rumah. Baumrind (dalam Santrock, 2002)

Orangtua adalah pendidik pertama dan utama dalam keluarga. Bagi anak, orangtua adalah model yang harus ditiru, diteladani. Sebagai model, orangtua harus memberikan contoh yang terbaik bagi anak dalam lingkungan keluarga. Seperti disebutkan oleh Fhadlillah (2012) bahwa lingkungan keluarga adlah merupakan lingkungan awaal bagi seorang anak, segala tingkah laku maupun perkembangan yang muncul pada diri anak akan mencoontoh pada kedua orangtuanya. Sikap dan perilaku orangtua harus mencermiinkan akhlak yang muulia.

Peran orangtua dalam keluarga sangat vital terhadap tumbuh kembang anak. Salah satu faktor penentu pada proses pembentukan karaakter anak adalah pola asuh orangtua. Seperti pendapat Wardhani dalam Nilawati (2013) penndidikan orangtua akan membeerikan pengaruh terhadap pola berpikir serta orientasi pendidikan yang di berikan kepada anaknya. Pola asuh dapat diartikan sebagai model, sistem, cara kerja, beentuk atau struktur yang digunakan oleh orangtua secara berulangulang secara koonsisten baik disadari maupun tidak disadari dalam proses mendidik atau mengasuh anak. Pola asuuh juga sangat menentukan karakter, sifat, serta pemikiran setiap anak dalam suatu keluarga (Jainuddin dkk, 2020).

Penelitian ini bertujuan untuk mendeskripsikan pola asuh yang di terapkan orangtua pada siswa SD, pengaruh pola asuh orangtua dalam membentuk perilaku sosial peserta didik SD, pengaruh pola asuh orangtua terhadap pretasi belajar peserta didik SD di Kecamatan Tamalanrea Kota Makassar

Dalam proses mendidik anak, pola asuh menjadi faktor penentu terhadap kemampuan akademik kemampuan sosial anak, di antaranya adalah perilaku sosial dan prestasi belajar. Di mana perilaku sosial diartikan sebagai kondisi atau keadaan hubungan antara dua atau lebih manusia yang saling berhubuungan secara timbal balik. Adapun prestasi belajar diartikan sebagai pencapaian proses belajar baik dinilai secara kuantitas, maupun kualitas. Kedua hal ini, baik perilaku sosial maupun prestasi belajar, telah banyak dibuktikan, bahwa di pengaruhi oleh pola asuh orangtua. Oleh karena penulis telah mengangkat judul penelitian pengaruh Pola Asuh Orangtua pada Prestasi dan Perilaku Sosial Peserta Didik SD di Kecamatan Tamaalanrea Kota Makassar.

\section{Metode Penelitian}

Tipe penelitiian yang digunakan adalah tipe penelitian deskriptif kuantitatif dan desain penelitian ini dilakukan mennggunakan angka-angka dan pengelolaan statistik. Tempat penelitian dilakukan di tiga sekolah dasar di Kecamatan Tamalanrea Kota Makassar. Adapun variabel yang digunakan dalam pada penelitian ini adalah Variabel sangat bebas (X) pola asuh orangtua. Variabel terikat (Y) prestasi belajar peserta didik. Teknik Analisis data yaitu Analisis statistik deskriptif.

\section{Hasil dan Pembahasan}

Hasil penelitian, yang di lakukan peneliti, terdiri (1) pola asuh yang diterapkan orangtua pada peserta didik SD di Kecamatan Tamalanrea Kota Makassar, (2) pengaruh pola aasuh orangtua dalam membeentuk perilaku sosial peserta didik SD di Kec Tamalanrea Kota Makassar, dan (3) pengaruh pola asuh orangtua terhadap pretasi belajar siswa SD di Kecamatan Tamalanrea Kota Makassar. Berdasarkan hasil penelitian yang dilaksanakan di Sekolah Dasar Kecamatan Tamalanrea Kota 
Makassar dengan popuulasi penelitian, SD yang ada di Kecamatan Tamalanrea Kota Makassar dan sampel yang digunakan sebagai berikut:

Tabel. 1. Sampel penelitian Sekolah Dasar di Kecamatan Tamalanrea Kota Makassar

\begin{tabular}{clcc}
\hline No. & Nama Sekolah Dasar & Jml Peserta didik kelas V & Sampel Penelitian \\
\hline 1 & SD Inpres Tamalanrea 1 & 35 peserta didik & 17 \\
2 & SD Inpres Tamalanrea 4 & 35 peserta didik & 17 \\
3 & SD Inpres Tamalanrea 5 & 34 peserta didik & 16 \\
\hline
\end{tabular}

Sumber: Analisa Data, 2020.

Pada pengaruh pola asuh orangtua, terhadap preestasi belajar dan perilaku sosial peserta didik sekolah dasar di Kecamatan Tamalanrea Kota Makassar untuk mengetahui apakah ada pengaruh pola asuh orangtua terhadap prestasi belajar peserta didik sekolah dasar di Kecamatan Tamalanrea Kota Makassar. Analisis yang digunakan adalah analisis statistik deskriptif. Analisis statistik deskriptif digunakan dalam hipotesis ini, karena siswa memiliki hasil prestasi belajar berupa buku penilaian rapor. Statistik deskriiptif di gunakan supaya memberikan gambaran profil, data sampel. Penelitian ini juga meng gunakan statistik deskriptiif yang terdiri dari minimum, maksimum, mean dan deviasi standar. Standar deviasi merupakan cerminan dari rata penyimpangan data dari mean. Standar deviasi juga dapat menggambarkan seberapa jauh bervariasinya data. Jika nilai standar deviasi jauh lebih besar di bandingkan nilai mean, maka nilai mean merupakan representasi yang buruk dari keseluruhan data. Sedangkan jika nilai itu standar deviasi sangat kecil dibandingkan nilai mean maka maka nilai mean dapat digunakan untuk sebagai representasi dari keseluruhan data. Sehingga dapat dideskripsikan sebagai berikut:

Deskripsi Pengaruh Pola Asuh Orangtua Terhadap Prestasi Belajar Sekolah Dasar di Kecamatan Tamalanrea Kota Makassar

Statistiik deskriptif merupakan statistika yang di gunakan di dalam mendiskripsikan data menjadi iinformasi yang lebih jelas serta mudah dipahami yang memberikan gambaran mengenai penelitian berupa hubungan dari variabel- variabel indeependen yang dikaitkan dengan pola asuh dan prestasi belajar. Pada tabel 4.2 dapat dilihat bahwa responden yang menyaatakan sangat setuju sebanyak 28 orang (56\%), sementaara yang menyatakan baik sebanyak 20 orang (44\%), yang menyatakan cukup sebanyak Nol dan yang yang menyatakan kurang sebanyak Nol. Hasil penelitian analisis statistik deskriiptif dapat di lihat dalam Tabel 2 di bawah ini:

Tabel. 2. Statistik Deskriptif

\begin{tabular}{l|l|c|c}
\hline No. & \multicolumn{1}{|c|}{ Jawaban Responden } & Frekuensi & Presentase \\
\hline 1. & Sangat Baik & 28 & 56 \\
2. & Baik & 22 & 44 \\
3. & Cukup & 0 & 0 \\
4. & Kurang & 0 & 0 \\
\hline Jumlah & \multicolumn{1}{c|}{$\mathbf{1 0 0}$} & \\
\hline
\end{tabular}

Sumber: Analisa Data, 2020.

Pengaruh Pola Asuh Orangtua Terhadap Perilaku Sosial Peserta Didik Sekolah Dasar di Kecamatan Tamalanrea Kota Makassar

Pola asuh yang membentuk perilaku sosial peseerta didik terbagi atas tiga, yaitu demokratis, otoriter dan permisif Berdsarkan hasil pengumpulan data yang telah dilakukan melalui lembar angket dengan memberikan 5 butir pernyataan pola asuh demokrasi, 5 butir pernyaataan otoriter dan 10 butir pernyataan permisif, maka dapat dilihat haasil pengumpulan data pada tabel yang telah tersaji dibawah ini:

Tabel 3 Perilaku Sosial Peserta Didik Sekolah Dasar di Kecamatan Tamalanrea Kota Makassar

\begin{tabular}{c|c|c|c}
\hline Jenis Pola Asuh & Frekuensi & Nilai Minimum & Nilai Maksimum \\
\hline Permisif & 10 & 16 & 18 \\
Otoriter & 5 & 10 & 16 \\
Demokratis & 5 & 15 & 19 \\
\hline Total & 20 & & \\
\hline
\end{tabular}

Sumber: Analisa Data, 2020.

Berdasarkan data angket perilaku sosial peserta didik yang ditampilkan pada tabel diatas diketahui bahwa pola asuh yang dominan digunakan orangtua dalam mendukung pertumbuhan peserta didik yaitu padaa pola asuh demokratis, karena nilai maksimum yang ditunjukkan pada pola asuh demokratis lebih besar, di bandingkan dengan pola asuh lainnya. Selain itu, orangtua juga merasakan bahwa bebeerapa pola asuh yang digunakan adalah pola asuh otoriter karena nilai maksimum yang di tunjukkan 16. Oleh karena itu, peneliti dapat menyimpulkan, bahwa pola asuh yang banyak digunakan oleh orangtua di SD Kecamatan Tamalanrea adalah pola asuh demokraatis.

Tabel 4. Statistik Deskriptif

\begin{tabular}{c|l|c|c}
\hline No. & \multicolumn{1}{|c|}{ Jawaban Responden } & Frekuensi & Presentase \\
\hline 1. & Sangat Setuju & 20 & 40 \\
2. & Setuju & 16 & 32 \\
3. & Ragu-ragu & 14 & 28 \\
4. & Tidak Setuju & 0 & 0 \\
\hline & \multicolumn{1}{|c|}{ Jumlah } & $\mathbf{N = 5 0}$ & $\mathbf{1 0 0}$ \\
\hline \hline
\end{tabular}


Dari Tabel 4 dapat dilihat, bahwa respondeen yang meenyatakan sangat sangatsetuju sebanyak 20 orang (40\%), sementara yang menyatakan setuju, sebanyak 16 orang (32\%), yang menyatakan ragu-ragu sebanyak 15 orang (28\%) dan yang juga menyatakan tidak setuju sebanyak 0 orang $(0 \%)$.

\section{Pengaruh Pola Asuh Orangtua Terhadap Prestasi Belajar PesertaDidik Sekolah Dasar di Kec Tamalanrea Kota Makassar}

Berdasarkan data, jawaban responden paling terbanyak yaitu 28 orang $(56 \%)$ dari 50 responden menjawab sangatsangat setuju dengan pernyataan pola asuh orangtua berpengaruh terhadap prestasi belajar Sekolah Dasar di Kec Tamalanrea Kota Makassar. Jadi ddapat disimpulkan, bahwa data tersebut menunjukkan banyak orangtua yang mengangap bahwa pola asuh memengaruhi prestasi belajar peseerta didik. Sehingga orangtua selalu memberikan perhatian serta motivasi yang dapat membentuk direi dari peserta didik saat berada di rumah, terlebih lagi saat proses pembelajaran di sekolah.

Hasil prestasi belajar siswa menunjukkan hasil yang sangat baik, karena pembelajaran di atas KKM setiap mata pelajaran di masing-masing sekolah. Khususnya pada sekolah yang telah ditunjuk sebagai sekolah penelitian oleh peneliti.

Berdasarkan data terseebut menunjukkan banyak orangtua yang menganggap bahwa, pola asuh sangat memengaruhi prestasi belajar peserta didik. Sehingga orangtua selalu memberikan perhatian serta motivasi yang dapat membeentuk diri dari peserta didik saat berada di rumah, terlebih lagi saat proses pembelajaran di sekolah.

Hal ini disebabkan, karena kriteria dan skala penilaian penetapan KKM, sudah sesuai dengan yang dilakukan oleh sekolah. Sehingga berdasarakan daata yang telah diperoleh dari hasil wawancara dan angket yang diberikan kepada orangtua yang disesuaikan dengan hasil prestasi belajar siswa melalui buku laporan hasil belajar selama satu semester. Nilai yang didapatkan oleh peserta didik sebagai sampel dalam penelitian ini menuunjukkan nilai semua mata pelajaran di atas KKM, sehingga orangtua sangat merasa baik atas atas hasil yang telah diperoleh masing-masing anaknya. Begitupun dengan konveksii kompetensi pengetahuan, keterampilan dan sikap sesuai dengan KKM yang telah ditetapkan oleh pihak sekolah.

Berdasarkan hasil prestasi belajar siswa menunjukkan hasil yang sangat baik, karena pembelajaran di atas KKM setiiap mata pelajaran di masing-masing sekolah. Khususnya pada sekolah yang telah ditunjuk sebaagai sekolah penelitian oleh peneliti.

Pengaruh Pola Asuh Orangtua Terhadap Perilaku Sosial Peserta Didik Sekolah Dasar di Kecamatan Tamalanrea Makassar

Pengaruh Polaasuh Orangtua Terhadap Prestasi Belajar dan Perilaku Sosial Peserta Didik Sekolah Dasar di Kecamatan Tamalanrea Kota Makassar untuk mengetahui apakah ada pengaruh pola asuh orangtua terhadap perilaku sosial peserta didik sekolah dasar di Kecamatan Tamalanrea Kota Makassar. Analis yang akan di gunakan adalah analisis statistik deskriptif.

Data pada jawaban responden, paling terbanyak yaitu 20 orang $(40 \%)$ dari 50 responden menjawab setuju dengan pernyataan saya merasa perilaku sosial peserta didik berasal dari pola asuh yang diterapkan oleh orangtua dalam kehidupan sehari-harinya. Jadi dapat kita disimpulkan, bahwa data tersebut banyak yang sangat setuju, jika orangtua yang menjadi cikal bakal sehingga peserta didik memiliki perilaku sosial yang positif.

Data menunjukkan banyak orangtua yang mengangap bahwa pola asuh memengaruhi perilaku sosial peserta didik. Sehingga orangtua menagnggap pola asuh yang diberikan kepada anaknya merupakan peembentukan jati diri serta perilaku anak dalam berkehidupan sosial.

Oleh karena itu, hasil penelitian yang telah di lakukan bahwa pola asuh yang banyak digunakan olehorangtua di SD seKecamatan Tamalanrea adalah pola asuh demokratis. Hal ini sesuai dengan teori utama yang menjadi dasar diadakannya penelitian ini, bahwa pola asuh yang dapat menjadi panutan bagi seluuruh orangtua yaitu pada pola asuh demokratis, karena akan melahirkan anak yang percaya diri sekaligus mudah menjalin komunikasi dengan individu lainnya. Terlebih lagi jika berkaitan dengan perilaku sosial yang bersifat positif di kehidupan bermasyarakat.

Sebagian orangtua mengaanggap setiap anak perlu diberikan pemahaman tentang perilaku yang berlaku dikehidupan sehari-hari, termasuk kehidupan dalam berperilaku sosial. Sehingga orangtua menggunakan berbagai macam pola asuh, dalam mendidik anak dalm kehidupan sehari-hari.

Perilaku sosial peserta didik dapat tergambar jelas saat berada dalam kehidupan sehari-harinya, khususnya pada saat di sekolah. Komunikasi serta interkasi yang dibangun oleh peserta didik tercermin, dari pola tingkahlaku serta kebiasaan yang mereka dapatkan di rumah, utamanya dalam perilaku sosial.

\section{Pengaruh PolaAsuh Orangtua Terhadap Prestasi Belajar dan Perilaku Sosial Peserta Didik Sekolah Dasar di Kecamatan}

\section{Tamalanrea Kota Makassar}

Berdaasarkan ini penghitungan menunjukkan $F_{\text {hitung }}(10.670)>F_{\text {tabel }}(3.132)$ dan tingkat signifikansi $0,000<0,05$. Hasil pengujian menunjukkan bahwa nilai signifikansi uji serempak (uji F) diperoleh nilai 0,000, dengan demikian, nilai sihgnifikansi yang diperoleh lebih kecil daripada probabilitas $\alpha$ yang ditetapkan $(0,000<0,05)$. Jadi $\mathrm{H}_{0}$ ditolak serta $\mathrm{H}_{\mathrm{a}}$ diterima. Jadi dapatlah ditarik kesimpulan terdapat pengaruh yang signifikan antara polaasuh orang tua terhadap prestasi belajar dan perilaku social dengan nilai signifikansi 0,000 .

Hal ini sesuai dengan, menurut Zhakiyah Darajat yang mengungkapkan bahwa orangtua di dalam kehidupan keluarga mempunyai posisi sebagai kepala keluarga atau pemimpin rumah tangga "orangtua sebagai pembentuk, pribadi kesatu dalam kehidupan anak, kepribadian orangtua, sikap dan cara hidup mereka merupakan unsur pendidikan yang tidak langsung, yang dengan sendirinya akan masuk ke dalam pribadi anak- anak yang sedang tumbuh". Dengan demikian orangtua tidak hanya cukup untuk memberi makan, serta dan pakaian saja kepada anak-anaknya tetapi harus berusaha agar anaknya menjadi baik, pandai, bahagia dan berguna bagi hidupnya dan masyarakat.

Orangtua dituuntut harus dapat mengasuh, mendidik dan mengembangkan semua potensi yang dimiliki anaknya agar dapat secara jasmani dan rohani dapat berkembang secara optimal. Masing-masing orang tua tentu saja memiliki pola asuh yang berbeda-beda terhadap anaknya. Hal ini sangat dipengaruhi oleh latar beelakang pendidikan orangtua, sebagai mata pencaharian hidup, keadaan sosial ekonomi, adat istiadat dan sebagainya. Ada yang menerapkan dengan pola yang kasar/ 
kejam, kasar, dan tidak berperaasaan. Namun, ada pulalah yang memaakai pola lemah lembut, dan kasih sayang. Ada pula yang memakai sistem militer, yang apabila anaknya bersalah akan langsung dapat diberi hukuman dan tindakan tegas (pola asuh otoriter). Dengan pola asuh yang baik teerhadap siswa dapat meningkatkan prestasi belajar dan perilaku sosial peserta didik SD di Tamalanrea Kota Makassar.

\section{Kesimpulan dan Saran}

Hasil penelitian dapat disimpulkan bahwa terdapat pengaruh dari pola asuh orangtua terhadap pada prestasi belajar peserta didik SD di Kecamatan Tamalanrea Makassar. Hal tersebut dilihat dari responden yang menyatakan sangat baik sebanyak pada 28 orang (56\%), sementara yang menyatakan baik sebanyak 20 orang (44\%), yang menyatakan cukup sebanyak Nol serta yang menyatakan kurang sebanyak Nol. Berdasarkan data tersebut jawaban responden paling terbanyak yaitu 28 orang $(56 \%)$ dari 50 responden ini menjaawab sangat baik dengan pernyataan pola asuh orangtua berpengaruh terhadap prestasi belajar sekolah dasar di Kecamatan Tamalanrea Kota Makassar. Terdapat pengaruh dari pola aasuh orangtua terhadap perilaku sosial peserta didik SD di Kecamatan Tamalanrea Kota Makassar. Perilaku sosial peserta didik dapat tergambar jelas saat berada dalam kehidupan sehari-harinya, khususnya pada saat di sekolah bahwa pola asuh yang menjadi dasar dari orangtua yaitu poola asuh demokratis sehingga dapat menjadi panutan bagi seluruh orang tua, karena akan melahirkan anak yang percaya diri sekaligus mudah menjalin komunikasi dengan individu lainnya. Komunikasi dan interkasi yang dibangun oleh peserta didik tercermin, dari pola tingkah laku dan kebiasaan yang mereka dapatkan di rumah, utamanya dalam perilaku sosial.Terdapat pengaruh dari pola asuh orangtua terhadap prestasi belajar dan perilaku sosial peserta didik sekolah dasar di Kecamatan Tamalanrea Kota Makassar. Hal ini berdasarkan nilai Asymptotic Sig sebesar 0,000 yang artinya kuraang dari Sig alpha yang ditentukan yaitu 5\% $(0,05)$ maka ada pengaruh yang signifikan dengan pengaruh pola asuh orangtua terhadap prestasi belajar dan peerilaku sosial peserta didik.

Diharapkan pada orangtua mampu memberikan kontribusi terhadap pendidikan anaknya, termasuk perilaku yang dimiliki oleh anak. Maka hendaknya orangtua disarankan menerapkan pola asuh demokratis bagi anak-anaknya, sehingga dapat memberikan pengaruh yang positif terhadap prestasi belajar anak di sekolah.

\section{Daftar Pustaka}

Darmawan, F. A., \& Jainuddin, J. (2021). Augmented Reality-based Mathematics Worksheet for Online Learning During Covid-19 Pandemic. Indonesian Journal of Educational Studies, 23(2), 81-90.

Dipalaya, T. (2020). Field Experience Practices Based Lesson Study (Ls) To Improve Students Communication Skills And Collaboration. Klasikal: Journal Of Education, Language Teaching And Science, 2(1), 48-62.

Elizabeth B, Hurlock. 1997. Psikologi perkembangan: Suatu Pendekatan Sepanjang Masa Edisi ke V. Jakarta: Erlangga.

Fadlillah, Muhammad. 2012. Desain pembelajaran PAUD. Jogjakarta: Ar-Ruzz Media.

Jainuddin, J. (2019). Peningkatan Hasil Belajar Matematika Melalui Latihan Menyelesaikan Soal Secara Sistematis Pada Siswa Kelas XI. IPA1 SMA Negeri 2 Sungguminasa. Klasikal: Journal Of Education, Language Teaching And Science, 1(3), 44-52.

Jainuddin, J., \& Sirajuddin, S. (2020). Pengaruh Minat dan Kedisiplinan Siswa dengan Gaya Kognitif Field Indefendent terhadap Hasil Belajar Matematika Siswa SMK Farmasi Yamasi Makassar. Delta-Pi: Jurnal Matematika dan Pendidikan Matematika, 9(2).

Lestari, Putri Budi Suci. 2013. Hubungan antara Pola Asuh Otoritatif Dengan Kemandirian Pada Peserta didik Kelas XI Jurusan Akuntansi Smkn 12 Jakarta. Jurnal. JurnalPendidikan Ekonomi dan Bisnis (JPEB), Vol. 1 No. 2 Oktober 2013: Jakarta.

Nilawati, I., Sumarni., \& Santjaka, A. (2013). Hubungan dukungan ibu dengan kecemasan remaja dalam menghadapi menarche di SD Negeri lomanis 01 Kecamatan Cilacap Tengah Kabupaten Cilacap. Akademi Kebidanan YLPP Purwokerto.

Santrock, J. W. 2002. Life-Span Development: Perkembangan Masa Hidup. Edisi 5. Volume 1. Jakarta: Erlangga

Sardiman, A. M. 1990. Interaksi dan Motivasi Belajar Mengajar, Pedoman Bagi Guru dan Calon Guru. Jakarta: Raja Grafindo Persada 